\title{
Menneskerettigheter og Den russisk- ortodokse kirke: opportunisme, autoritarianisme eller ortodoks nasjonalisme?
}

\author{
Hans Morten Haugen ${ }^{\star}$ \\ Cand.polit, dr. juris, professor i internasjonal diakoni, VID vitenskapelige høgskole, \\ studiested Diakonhjemmet
}

\begin{abstract}
Human Rights and the Russian Orthodox Church: Opportunism, Authoritarianism or Orthodox Nationalism?

The Russian Orthodox Church (ROC) as a traditional majority church enjoys a privileged position in the Russian society. The current Russian regime has strengthened ROC's position, and the alliance between the two has strengthened the emphasis on traditional values. With emphasis on the very nature of Orthodox Christianity, the article seeks to explain variations in ROC's understanding of and receptiveness of human rights, emphasizing rights that protect certain groups of people, including refugees and minorities. Four explanations are identified: national heritage; whether new minorities are considered a threat to this legacy; how the church understands its relationship with the state; and the organizational structure of the church, influenced by the prevailing political culture. ROC has a self-understanding of being the keeper of the Russian national heritage, and is skeptical of influences other than those coming from the tradition and state. Relevant orthodox theological concepts are introduced as explanations: symphony (harmonious relationship between state and church), pomestnost (national embeddedness), sobornost (the self as part of the collective) and the teosis (also referred to as "bogochelovek", human divinity).
\end{abstract}

Keywords: Russian Orthodox Church, ecclesiology, church-state, national-cultural values human rights, symphony, Patriarch Kirill

\section{Innledning}

Russlands nye lover skaper ofte internasjonal oppmerksomhet, som loven om administrative forseelser da den i 2013 fikk et forbud (\$ 6.21) mot å spre "propaganda» for homofili (SRAS 2013), og NGO-loven fra 2012, som definerer organisasjoner som mottar pengestøtte fra utlandet og bedriver «politisk virksomhet» som «utenlandske agenter» (Den norske Helsingforskomité 2014). Andre lovendringer er mindre bemerket, som endringen i 2013 av artikkel 148 i straffeloven, som forbyr

^Kontaktinformasjon: Hans Morten Haugen. Email: hans.morten.haugen@vid.no 
«offentlige handlinger som uttrykker grunnleggende mangel på respekt for samfunnet og med formål å fornærme religiøs tro (OSSE 2017: 198).

Disse lovendringene viser den skepsis mot utviklingen innenfor menneskerettigheter som man finner hos mange russere (Gerber and Mendelson 2001), deriblant i Den russiske ortodokse kirken (ROK). Denne artikkelen søker å identifisere forklaringer på disse holdningene. Jeg forstår her menneskerettigheter som rettslige krav som kan påberopes overfor statlige myndigheter for å ivareta ens fysiske og mentale integritet, og en viss materiell levestandard. Menneskerettighetsvernet omfatter ikke bare individer men også kollektiver, som familien, minoriteter og folk.

Artikkelen vil benytte to tilnærminger. For det første kan mottakeligheten for menneskerettigheter i majoritetskirker forstås ved å studere disse kirkenes politiskreligiøse tradisjon der kirkene søker å ivareta sine institusjonelle interesser (Minkenberg 2009: 1195-1196), og der tette bånd mellom kirke og stat begrenser kritikk fra kirkene (Minkenberg 2008a: 377). Denne formen for stiavhengighet kan forklare ortodokse kirkers statslojalitet (Vetvik 1992: 20).

For det andre kan vi studere mottakeligheten for menneskerettigheter gjennom en situasjonsbestemt tilnærming ("contingency theory»). Stoeckl (2016: 133-134) anser at det er tre sentrale retninger i ROK: fundamentalister, tradisjonalister og liberalere, og at tradisjonalistenes posisjon og ideologi - forsvar av tradisjonelle verdier - er styrket i den senere tid. Horsfjord (2012) identifiserer to dominerende diskurser i ROK: en som er åpen for å utforske forholdet mellom menneskerettighetene og doktrinene til ROK ("pluralistisk diskurs»), og en som ser menneskerettighetene som en sekulær ideologi som ROK må avvise («absolutistisk diskurs»), og han peker på at begge kan finnes side om side i samme dokument (Horsfjord 2012: 431). Siden Stoeckl opererer med tre kategorier og Horsfjord opererer med to kategorier er det ikke lett å føre disse sammen til en omforent modell, men det er sentralt å understreke at både Stoeckl og Horsfjord peker på maktspillet som har foregått og fortsatt foregår innad i ROK.

Selv om oppmerksomheten er på menneskerettigheter, er det nødvendig med to presiseringer: Rettighetsvernet for etablerte religioner og nasjonale minoriteter, med andre ord minoriteter som tradisjonelt har hatt tilhørighet i Russland, er relativt godt. Med sin enorme utbredelse har Russland alltid vært flerkulturelt og flerreligiøst. Det er altså hovedsakelig personer som uttrykker seg på måter som strider mot tradisjonen, som opplever menneskerettighetsproblemer (Staalesen 2004). Videre vil ikke artikkelen inneholde en grundig analyse av de konkrete menneskerettighetene slik de gjelder for slike nye minoriteter.

Det er verdt å merke seg at selv om ROK har hatt en privilegert posisjon, har ikke ROK en forankring i den russiske grunnloven. I studien $A$ World Survey of Religion and the State skårer Russland relativt høyt på variabelen "statlig engasjement» (Fox 2008: 108 og 141), mens en annen klassifisering plasserer Russland som «sekulær» og med «begrensede subsidier» (Madeley 2003: 16). Det er også relevant å minne om at Russland er blant de europeiske landene med lavest religiøs aktivitet. ${ }^{1}$

${ }^{1}$ Ifølge European Social Survey (ESS) 2012 svarer 57,5 prosent av russerne å være gjennomsnittlig eller under gjennomsnittet religiøs (spørsmål C13 i ESS, skåre 5 eller lavere), og 75,2 prosent 
Mange vil likevel ha en religiøs tilhørighet («belonging»), i fravær av tro («believing») og aktiv kirkedeltakelse («behaving»).

Derfor er det nødvendig å supplere oppmerksomheten på institusjonelle forhold med forklaringer forankret i kultur. Russisk nasjonalisme har blitt karakterisert som «reaksjonær-romantisk autoritarianisme», med vekt på den idylliske fortiden (Hvithamar og Warburg 2009: 5; se også Ramet 2006 og Furman 1994: 13). Curanovic (2007: 302) løfter fram begrepet «symfoni» for å beskrive det nære forholdet mellom kirke og stat i den ortodokse verden, et begrep som ROK selv omtaler som «gjensidig ikke-innblanding i hverandres forhold» (ROK 2000: avsnitt III.3; se også OrthodoxWiki 2010). «Symfoni» kan også forstås som at kirke og stat arbeider for de samme målene med forskjellige midler, og ved å rettferdiggjøre de midler som er valgt av den andre. Det finnes også andre mer spesifikke russiske begreper som vi kommer tilbake til: lokal forankring («pomestnost»), individuell frihet i en kollektiv ramme («sobornost») og streben etter å bli Gud-lignende.

Artikkelen fortsetter som følger: Først, ved å studere relevante uttalelser, identifiseres ROKs holdninger og mottakelighet for menneskerettighetene. Deretter forklares disse uttalelsene ut fra de to hovedforklaringene knyttet til stiavhengighet og kirkelige strategier. Dernest konkluderer artikkelen ved å diskutere den generelle anvendelighet av de forklaringer som er presentert.

Følgende problemstilling strukturer artikkelen: Hvilke samfunnsmessige faktorer $i$ fortid og nåtid, og hvilke kirkespesifikke (ekklesiologiske) faktorer $i$ fortid og nåtid forklarer oppfatningen av menneskerettigheter $i$ Den russiske ortodokse kirken?

Som nevnt over er oppmerksomheten særlig på menneskerettigheter for dem som uttrykker seg på ikke-tradisjonelle måter.

\section{Sosiallæren, Menneskerettighetslæren og Menneskerettighetserkæringen - og reaksjonene på dem}

En innføring i lederstrukturen i ROK er nødvendig. Formelt er det høyeste organ Det lokale konsil (Pomestnyi Sobor), som vedtektene sier det «skal innkalles ved behov» (ROK 2013) - og som har møtt bare fem ganger siden revolusjonen: 1945, 1971, 1988, 1990 og 2009, først og fremst for å velge nye patriarker. I praksis er derfor Bispemøtet det høyeste organet. Videre finnes Det russiske folkekonsilet («Folkekonsilet», Vsermirnyi Russkii Narodnyi Sobor), som formelt er en NGO ledet av patriarkatet, etablert i 1993. Folkekonsilet kan betraktes som et verktøy for ROK, og hevdes å ha «fostret sterkere nasjonalisme i ROK» (Stoeckl 2014: 30).

Ytterligere to organer i ROK må kort nevnes - selv om disse ikke er sentrale, verken i ROK eller i artikkelen: Kirkerådet og Den hellige synode, som var ROKs øverste myndighet i perioden 1721-1917. Kirkerådet skal være «underordnet og ansvarlig overfor (...) Den hellige synode» (ROK 2013 «Supreme Church Council»: \2). Kirkerådet

sjelden delta på religiøse tjenester (spørsmål C14 i ESS, de som svarer «bare på spesielle helligdager», «sjeldnere» eller «aldri»). Tall fra World Value Survey (Pankhurst og Kilp 2013: 237) viser at russere er blant de minst religiøse personer i Europa. 
består av 20 medlemmer der alle med ett unntak er geistlige (ROK 2015). Den hellige synode består av 15 geistlige, og er underlagt Bispemøtet. ROK er altså - med unntak for NGO-en Folkekonsilet (1993) - styrt av patriarken, metropolitter og biskoper.

To dokumenter vedtatt av Bispemøtet og ett dokument vedtatt av Folkekonsilet skal analyseres: Sosiallæren (ROK 2000), Menneskerettighetslæren (ROK 2008) og Menneskerettighetserklæringen (Folkekonsilet 2006). Sosiallæren presiserer at den uttrykker "grunnleggende bestemmelser i hennes [ROK] lære om kirkestat-relasjoner og (...) den offisielle posisjonen til Moskvapatriarkatet om forholdet til staten og det verdslige samfunnet» (ROK 2000, innledning, 1. avsnitt). Menneskerettighetslæren innledes med at ROK må bekrefte «kristen lære om mennesket» i lys av menneskerettighetene (ROK 2008, innledning, 3. avsnitt). Menneskerettighetserklæringen gir ikke inntrykk av å være annet enn nettopp en «erklæring», og blir derfor viet minst oppmerksomhet i denne artikkelen.

\section{Sosialleren og Menneskerettighetsleren fra Bispemøtet og Folkekonsilets}

\section{Menneskerettighetserkcering}

Sosiallæren advarer mot «lære som setter nasjonen i Guds sted eller reduserer troen til ett av uttrykkene for nasjonal selvbevissthet» (ROK 2000: II.4), og mot «aggressiv nasjonalisme, fremmedfrykt, nasjonal eksklusivitet og inter-etnisk fiendskap» (ROK 2000: II.4). På den annen side bekrefter dokumentet en sterk sammenheng mellom kirke og nasjon. Selv om det fastholdes at kristendommen er universell, flyttes fokus til kristen patriotisme og "en ortodoks nasjon» (ROK 2000: II.3).

Sosiallæren sier at det ideelle kirke/stat-forhold «kan oppstå i historien bare i en stat som anerkjenner den ortodokse kirke som den største helligdom, med andre ord bare i en ortodoks stat» (ROK 2000: III.4). Et etterfølgende avsnitt sier at ROK «ikke gir preferanse til noe sosialt system eller noen eksisterende politiske doktriner» (ROK 2000: III.7). Både kravet om en «ortodoks stat» og mangelen på standpunkt til «politiske doktriner» er bemerkelsesverdig. Konsekvensen av å gi forrang til ortodoks kristendom er at andre kirker omtales som "pseudo-religiøse strukturer», som sies å presentere «en trussel mot den enkelte og samfunnet» (ROK 2000: III.8, avsnitt p). Mangelen på en presis definisjon av "pseudo-religiøse strukturer» kan åpne opp for uforutsigbarhet og maktmisbruk.

Et avsnitt om etikk legger vekt på menneskerettigheter, men med en negativ tilnærming. Ifølge Sosiallæren har sekularisme forvandlet menneskerettighetene fra å fremme "frihet» til å fremme "egenviljen", som innebærer "full avvisning av den moralske normen dersom avvisningen støttes av samfunnet» (ROK 2000: IV.7). Dessuten, når folkeretten er referert til (ROK 2000: XVI), er det innledningsvis lagt vekt på internasjonal rett som noe som er positivt i utgangspunktet, men der disse positive trekkene angivelig er blitt undergravd av globalisering og sekularisme. Snarere enn å understreke at menneskerettigheter spesielt eller folkeretten generelt kan gi et legitimt grunnlag for nasjonal lovgivning, må dokumentet forstås dit hen at nasjonal lovgivning vil være mest legitim dersom loven «oversetter Guds absolutte sannheter og tilpasser dem til konkrete historiske og nasjonale forhold» (ROK 2000: IV.8). 
Selv om ikke Sosiallæren tar til orde for teokrati, argumenterer den for at legitim lovgivning må være basert på det som presenteres som "den eneste sanne religion", altså ortodoks kristendom.

Vi tar nå for oss Menneskerettighetslæren fra 2008. Menneskerettighetskonseptet sies å ha to baser: moral og verdighet. Her er framhevingen av moral problematisk, da dette vil åpne opp for selektive vurderinger av hvem som kvalifiserer og hvem som ikke kvalifiserer for menneskerettighetsbeskyttelse. Menneskeverd, vanligvis forstått som at alle har lik verdighet i kraft av å tilhøre menneskeheten, er i utgangspunktet en solid basis å bygge på. En slik forståelse uttrykkes i fortalen til FNs Verdenserklæring om menneskerettighetene og FN-konvensjonene om sivile og politiske rettigheter, og om økonomiske, sosiale og kulturelle rettigheter. Et grunnleggende problem i ROK-dokumentene er imidlertid at begrepet verdighet knyttes til «verdighet i livsførsel», som videre forklart av Horsfjord (2012: 438).

Menneskerettighetslæren søker også - i tråd med Sosiallæren - å etablere en motsetning mellom «verdslig lov» (law of the flesh) og "moralske prinsipper nedlagt av Gud i menneskets natur» (ROK 2008: I.4.). Videre, ved å skille meget strengt mellom hva som er "moralsk» og hva som er «syndig» eller «ondt», og knytte sistnevnte til sekularisme, trer en eksklusiv forståelse av menneskerettigheter fram. Bare menneskerettigheter som vurderes som forenlig med en bestemt kristen moralsk forståelse kvalifiserer som egentlige menneskerettigheter.

Faktisk kan Menneskerettighetslæren leses dithen at moderne menneskerettigheter fremmer umoral. Menneskerettighetene hevdes å ha beveget seg i retning av å forsvare menneskelig valgfrihet, og at denne friheten kan rettferdiggjøre ondskap. Samtidig gis en spesiell forståelse av hva friheten handler om, ved å understreke at «frihet vil uunngåelig forsvinne hvis valget blir gjort til fordel for ondskap. Ondskap og frihet er uforenlige» (ROK 2008: II.2). Frihet forstås altså som å gjøre det "gode», slik ROK forstår dette.

Forholdet mellom menneskerettigheter og Guds innflytelse - forstått både som «kristne verdier» og «den åndelige verden» - ender opp med en rangordning der Guds innflytelse står øverst (ROK 2008: III.2). Menneskerettighetslæren inneholder oppfordringer til avklaring og definisjoner, men i realiteten er det uklare begreper og konkluderende utsagn som dominerer.

Det er ingen referanser til blasfemi i Menneskerettighetslæren, og mens utrrykket blasfemi brukes fem ganger i Sosiallæren, er det heller ikke der noen avklaring av begrepet. En senere uttalelse fra Bispemøtet presiserer at «blasfemi utgjør en ydmykelse av menneskeverdet til troende...» (ROK 2011:3,1, pkt. 4). Det er en sterk påstand å si at blasfemi kan ydmyke troendes menneskeverd. En slik påstand kan bare forstås ut fra den ortodokse teologien som preger ROK, som vi kommer tilbake til under.

Menneskerettighetslæren understreker også at menneskerettigheter «ikke bør undergrave kjærligheten til ens hjemland», og at menneskerettighetene «ikke kan settes mot verdier og interesser til ens hjemland, samfunnet og familien» (ROK 2008: III.5). Dette er uttrykk for en symfoni-tilnærming, som diskutert over. 
ROKs menneskerettighetstilnærming plasserer seg også langt fra en vestlig forståelse av menneskerettighetene når Menneskerettighetslæren tar for seg spesifikke menneskerettigheter. Om samvittighetsfriheten heter det at denne ikke kan brukes til å ødelegge sosial moral (ROK 2008: IV.3), noe som har blitt ytterligere presisert av daværende metropolitt av Smolensk og Kaliningrad (nå patriark) Kirill (2006). Videre utfordrer Menneskerettighetslæren ytringsfriheten ved å hevde at det er «særlig farlig å fornærme religiøse eller nasjonale følelser» (ROK 2008: IV.4); politiske rettigheter - ved å understreke «bevaring av sosial enhet» (ROK 2008: IV.7); og kollektive rettigheter, der det heter at «rettigheter bør ikke være ødeleggende for (...) ulike religiøse (...) fellesskap" (ROK 2008: IV.9). Disse formuleringene innebærer at det er en alvorlig fare for at dokumentet kan brukes til å begrense legitim utøvelse av menneskerettigheter, eksempelvis for dem som tilhører de såkalte "pseudo-religiøse grupper» (ROK 2008:V.2).

Derfor ser det ut som om bevaring av tradisjonelle verdier og nasjonalt samhold er det virkelige målet, og ikke realiseringen av menneskerettighetene. Samtidig er det relevant å påpeke at Menneskerettighetslæren understreker «gjensidig respekt for ulike livssyn...» som et prinsipp (ROK 2008: IV:5; se også Horsjord 2012: 442-443). Denne anerkjennelsen av ulike livssyn blir likevel vanskelig å se uttrykt når ord som «ondskap» knyttes til handlinger som hevdes å være mot læren til ROK.

Denne instrumentelle tilnærmingen som søker å fremme kollektive verdier og ikke individuelle rettigheter, er også tydelig i 2006-erklæringen, som sier at «det ikke finnes noe slikt som umoralsk verdighet» (Folkekonsilet 2006: avsnitt 4). Med denne forståelsen er verdighet noe som oppnås ved å opptre moralsk, og ikke noe mennesket har i kraft av å være et menneske. Skillet mellom verdi ("tsennost») som gitt og verdighet ("dostoinstvo») som oppnådd er ikke gientatt i Menneskerettighetslæren (Stoeckl 2012: 222). Menneskerettighetserklæringen forstår også menneskerettigheter i form av en "konflikt mellom sivilisasjoner ...», der ROK er en fortropp i å forsvare «den unike russiske sivilisasjonen ...» (Folkekonsilet 2006: fortalen).

Interessene som skal forsvares inkluderer «tro, moral, det hellige, fedrelandet» (Folkekonsilet 2006: avsnitt 7). Dette er uttrykk for en antagonistisk holdning til menneskerettigheter, der menneskerettigheter forstås som verktøy for å fremme moral, lojalitet og tradisjonelle verdier.

\section{Forklaringer på vektleggingen $i$ disse dokumentene}

Den mest omfattende analyse som er foretatt av de tre dokumentene (Stoeckel 2014) påpeker at de gjenspeiler reelle spenninger i ROK, og at mens den nasjonalistiske fløyen seiret i utformingen av Sosiallæren og Menneskerettighetserklæringen, var den moderate fløyen mer innflytelsesrik når Menneskerettighetslæren ble vedtatt (Stoeckl 2014: 57-58 og 86-87). Kort sagt finner Stoeckl ut fra en situasjonsbestemt tilnærming at det er en utvikling i retning av mer åpenhet i Menneskerettighetslæren.

Mens tidligere patriark Aleksej II understreket at Russland er "flerreligiøs», vektlegger hans etterfølger Kirill forståelsen av kristen ortodoks identitet hos landets 
innbyggere basert på at ROK er etablert på «kanonisk territorium» (Soldatov 2004: 75). I tillegg blir den russiske kulturen (《russkij») bekreftet av patriark Kirill å omfatte langt større områder enn staten Russland (Russkiy Mir Foundation 2014), der ROK er et viktig redskap i å fremme denne ikke-territorielle forståelsen av det russiske.

En slik forståelse gir seg utslag i at de væpnede styrker nå lærer om «ortodoks patriotisme» (Mozgovoj 2004: 59). Mens ROK formelt sett er en del av det sivile samfunn, ikke en del av staten, søker samtidig ROK å hindre andre organisasjoner i å påvirke statlig politikk, siden ROK ser på seg selv som den beste beskytter av russiske interesser.

Patriotisme ble understreket av nåværende patriark Kirill da han var metropolitt av Kaliningrad og Smolensk:

Vi kan ikke felle tårer for økende fremmedfrykt i en tid da vi ser personer som uten tanke på moral vanærer [ravage] hellige steder, spytter på sitt fedreland, og ødelegger sin kultur. (...) En slik person vil i neste omgang gå og drepe andre på grunnlag av rase eller tro. Det finnes én udelelig moral (Radio Free Europe 2006).

Vi ser at Kirill ved formuleringen «ikke felle tårer» framholder at fremmedfrykt er mindre beklagelig enn manglende fedrelandsrespekt.

I Menneskerettighetslæren - som altså Stoeckl framholder som uttrykk for de moderates stemme - søker ROK å presentere seg selv både som en minoritet som ønsker å bevare sin identitet, men også som et flertall som ønsker å opprettholde sin ledende sosiale posisjon (Agadjanian 2004: 103-104). Menneskerettighetslæren må også forstås som at ROK ønsker å gi forrang til hva som anses å være kollektive russiske verdier - som omfatter lojalitet og patriotisme - og ikke individuelle menneskerettigheter.

Alle dokumentene understreker at valgfriheten ikke kan brukes til å velge «det onde», og at verdighet oppnås dersom det valgte alternativet er "godt». I denne sammenheng er det relevant å bemerke at begrepet moral som er hyppig brukt, særlig i Menneskerettighetslæren, er «nravstvennost», som både omfatter moral i tradisjonell forstand og «en bevissthetstilstand» (Ladykowska sitert i Stoeckl 2014: 73).

Det er også interessant at ROKs dokumenter ikke stiller krav til politiske myndigheter, men til enkeltpersoner. Hvordan kan dette forklares?

Kirill legger vekt på at FNs menneskerettighetsinstrumenter inneholder ord som «plikter» og "moral» - se artikkel 29 i Menneskerettighetserklæringen - noe som er fraværende i Den europeiske unions charter om grunnleggende rettigheter (Stoeckl 2014: 61-62). Arbeid for tradisjonelle verdier i FNs Menneskerettighetsråd har skjedd med ROK i en aktiv pådriverrolle (Stoeckl 2012: 226; Stoeckl 2014: 106113). Horsfjord (2012: 447) peker på at ledelsen i ROK synes å fremme tradisjonelle verdier som et alternativ til menneskerettigheter. En annen forståelse av hvordan ROK-ledelsen forstår tradisjonelle verdier er at menneskerettigheter må være forankret i tradisjonelle verdier for å være legitime.

March (2012: 406) hevder at relasjonene mellom den russiske stat og ROK antakelig er svakere i dag sammenlignet med tsartiden da triaden av «ortodoksi, enevelde og nasjonalitet» utgjorde kjernen i offisiell russisk nasjonalisme, mens 
ortodoksien angivelig ikke spiller en like stor rolle i russisk nasjonalisme i dag. $\AA$ hevde at ortodoksien ikke inngår i kjernen av moderne russisk nasjonalisme er i det minste diskuterbart.

Uavhengig av hvilke endringer som faktisk har funnet sted, er det sterke felles interesser mellom den russiske stat og ROK i å bevare tradisjonelle verdier og fremme patriotisme og en anti-vestlig agenda. Gjennom å gjensidig legitimere hverandre bidrar ROK og dagens russiske regime til hverandres opprettholdelse.

Mens Stoeckl og March peker på en endring der dialogorienterte tradisjonalister nå preger ROK fremfor sterkt intolerante fundamentalister, er andre skeptiske til at vi faktisk ser slike endringer, og hevder at vi snarere ser en tilbakevending til ortodokse verdier (Agadjanian 2010: 100). Forklaringer på en slik tilbakevending finner vi i et felles ønske mellom regimet og ROK om en forent anti-vestlig front. I tillegg, som vi kommer tilbake til under, har vi sett en revitalisering av teologiske begreper om sakralisering av nasjoner og guddommeliggiøring av mennesker, og en utvidelse av fellesskapsbegreper til å omfatte fellesskapet skapt gjennom ROK.

Reaksjonene fra andre kirker på disse dokumentene

ROK inviterte andre kirker og organisasjoner til å kommentere innholdet i Menneskerettighetserklæringen. I 2009 svarte Fellesskapet av protestantiske kirker i Europa (CPCE) med å understreke en annen begrunnelse for menneskers verdighet enn ROK. CPCE tar avstand fra å forstå verdighet som et produkt av moralsk atferd, siden verdighet er noe alle mennesker har i kraft av å være menneske, forankret $\mathrm{i}$ Guds nåde og kjærlighet (CPCE 2009: 2).

Videre kritiserer CPCE den ortodokse posisjon som forutsetter harmoni mellom stat og kirke. Slik harmoni ("symfoni») kan føre til at statlig lov underordnes religiøs lov, noe som ifølge CPCE «motsier essensen av kirken» (CPCE 2009: 6).

Videre understreker CPCE betydningen av tros- og samvittighetsfrihet: «Fra et protestantisk perspektiv har kirkene en viktig oppgave i å motsette seg misbruk av statens makt (...)» (CPCE 2009, 7). Mens CPCE understreker betydningen av individets frihet, understreker ROK norm- og kulturbevaring og sosial enhet.

Vi så over at ROK har arbeidet i $\mathrm{FN}$ for å fremme tradisjonelle verdier. Mange katolsk-dominerte (og islam-dominerte) stater har støttet Russland i dette arbeidet (FNs Menneskerettighetsråd 2012; FNs Menneskerettighetsråd 2011; FNs Menneskerettighetsråd 2009; se også FNs Høykommissær for menneskerettigheter 2013 og FNs Menneskerettighetsråds Rådgivingskomite 2012).

Det er derfor rimelig å si at ROK med sin vekt på tradisjonelle og kollektive verdier avviker fra en vanlig vestlig forståelse av menneskerettigheter. ROKs posisjon utfordres av protestantiske kirker i Europa, men i mindre grad av katolske kirker.

\section{Samlet analyse av ROK og menneskerettigheter}

Jeg vil nå presentere mer inngående forklaringer på ROKs tilnærming til menneskerettigheter, der både den religiøse arven og ekklesiologi, samt situasjonsbestemte 
og institusjonelle forhold trekkes inn. Dette handler altså om å identifisere stiavhengighet og kirkelige strategier. Religionen er funnet å være viktig i å forklare stiavhengighet. På overordnet nivå er det funnet at den religiøse arven påvirker holdninger til multikulturalisme (Minkenberg 2008b: 45) og holdninger til demokrati (Norris og Inglehart 2011: 146 og 222).

Analysen struktureres under fire generelle antakelser som dekker historiske og nåværende forhold, der analysen beveger seg fra det generelle til det mer spesifikke.

1. Majoritetskirker brukes til å legitimere og implementere nasjonalistisk politikk.

2. Historiske forhold virker inn på interne strukturer i kirken.

3. Majoritetskirker søker å opprettholde sin status, noe som påvirker deres syn på innvandring og spørsmål om statsborgerskap.

4. Ortodokse majoritetskirker er generelt positive til å «sakralisere» hele nasjoner.

Majoritetskirkers legitimering og implementering av nasjonalistisk politikk

Vi skal identifisere kjennetegn ved den russiske nasjonalkulturelle arv som forklarer det tette samspillet mellom ROK og russiske myndigheter. Vi så at begrepet symfoni beskriver forholdet mellom kirke og stat i hele den ortodokse verden, men på russisk finnes det også to andre begreper som løftes fram av ROK og uttrykkes i Sosiallæren: pomestnost, altså lokal forankring (stedegen), og sobornost, som kan forstås som den kollektive rammen for utøvelse av den enkeltes personlighet (Hoppe-Kondrikova et al. 2013: 206-208).

En kort etno-religiøs og politisk historie er nødvendig. Den russisk-ortodokse identiteten er et resultat av en sammensmelting av slavisk kultur, bysantinsk religion og den autoritære arven etter mongolene (Tjønn 2015: 457-463). Fra det 14. århundre foregikk en territoriell ekspansjon av Moskvafyrstedømmet som en videreføring av Rus-riket (etablert i det 9. århundre, og alvorlig svekket av den mongolske invasjonen rundt 1240).

Den religiøse dimensjonen i den voksende russiske staten ble styrket ved at metropolitten flyttet fra Kiev til Moskva i 1299. Etter nederlaget til det bysantinske riket i 1453, så den russisk-ortodokse kirken seg selv som en videreføring av den sanne kirke. I tillegg bidro ekteskapet inngått i 1472 mellom Ivan III og Sophia Paleologue (Palaiologina), niesen til den siste bysantinske keiseren, til en selvoppfatning av Moskva som «det tredje Roma» (Østbø 2016; Tjønn 2015: 350-351; 353; 379; 386; Hoppe-Kondrikova et al. 2013: 202; 207; March 2012: 410; Smith 2009: 26). Ifølge OrthodoxWiki er dette synspunktet i dag bare uttrykt av enkelte prester i Den russiske ortodokse kirken utenfor Russland (ROKOR), ikke av den nåværende ledelsen av ROK (OrthodoxWiki 2013).

ROK hadde en privilegert posisjon under det russiske imperiet, og den ortodokse kirken ble delvis innlemmet i landets administrative struktur, slik vi også så i reformasjonskirkene i Vest-Europa (Papadikis 1983: 51). Etter at «stedfortredende locus tenens» (fra 1943: patriark) Sergei (Stragorodskij) utstedte en «lojalitetserklæring» i 1927, ble ROK plassert under myndighetenes fulle kontroll fram til 1988 - selv om 
graden av aktiv intervensjon varierte, med størst vanskeligheter i slutten av 1930-tallet og på begynnelsen av 1960-tallet (Davis 2003; Ramet 1998; Walters 1993). Denne autoritære og til tider også undertrykkende historien har medført at ROK har utviklet en ekklesiologi med vekt på kirkens overlevelse (Ramet 2006; Ramet 1983).

I samsvar med prinsippet om symfoni rommer ikke ortodoks teologi et klart skille mellom stat og kirke. ROK synes å være et villig redskap i å fremme «russifisering» (Ramet 2006; Ramet 1989). Videre har ROK blitt brukt til å utvide den russiske innflytelsen i nærområdene (Russkiy Mir Foundation 2014; Curanovic 2007) og i verden. Som et eksempel på det siste, mens ROK opererte under sterkt press, ble i 1961 ROK medlem av Kirkenes Verdensråd, angivelig «for å forsvare kommunistiske interesser (...)» (Ramet 2006: 149; Hebly 1993).

Dette tette forholdet er interessant i lys av den russiske grunnlovens bestemmelser. Artikkel 14.1 sier at Russland er en sekulær stat og forbyr statsreligion. Artikkel 14.2 lyder: «Religiøse foreninger skal skilles fra staten, og skal være like for loven.»Videre gir artikkel 28 et sterkt vern av religionsfriheten og artikkel 19.2 forbyr diskriminering og begrensninger av menneskerettigheter på grunnlag av religion.

Som oppsummering kan vi si at den russiske nasjonalismen har sitt utspring i forståelsen av en mektig stat med betydelig territoriell utstrekning, som søker å gjenvinne sin fortidige styrke. Den russiske nasjonalismen har i all hovedsak vært assimilerende. Videre er det russiske begrepet nasjon spesifisert som en nasion av russiske borgere ("Rossijskaja natsija»), ikke en etnisk russisk nasjon ("Russkaja natsija»). Russiske myndigheter ønsker også å imøtekomme alle historiske trossamfunn (jødedom, buddhisme og islam), eksemplifisert ved at Russland i 2005 ble observatør i Organisasjonen for islamsk samarbeid, en "gest som verken Tsar-Russland eller Sovjetunionen noensinne kunne tenkes å ha gjennomført» (March 2012: 411).

ROK er preget av patriotisme: «(...) Den russisk-ortodokse kirken utdannet de troende $\mathrm{i}$ ånden av patriotisme, og å elske fred. Patriotisme er manifestert i omsorg for fedrenes historiske arv (...)" (ROK 2000: III.4, gjengir en uttalelse fra Pomestny Sobor). Mens Sosiallæren advarer om at «nasjonale følelser kan føre til syndige fenomener som aggressiv nasjonalisme ...» (ROK 2000: II.4), er det ingen tvil om at aggressiv nasjonalisme finnes blant ROK-prester.

\section{Organiseringen av kirken, påvirket av den generelle politiske kulturen}

Slik vi ser av perioden siden kommunismens fall, er demokratisk kultur ikke sterkt forankret i det russiske samfunnet. Historien, slik ROK leser den, stadfester at ROK er den eneste institusjonen som har vært trofast med det russiske folk i århundrer av prøvelser. Dette har likevel ikke resultert i en økt rolle for lekfolket i styringen av ROK, selv om vi så innledningsvis at Folkekonsilet ble etablert i 1993.

Generelt i russisk politikk er det ikke lovgivning som eksplisitt søker å verne interessene til andre kristne trossamfunn, illustrert gjennom 1997-loven om samvittighetsfrihet og religiøse foreninger, vedtatt med 337 stemmer mot 5 (Religious Tolerance 2007; Codevilla 2008). Følgende vurdering er illustrerende: «Noen 
tjenestemenn i Russland mener det er ett tradisjonelt trossystem i Russland, og resten skal enten presses ut av Russland eller presses ned» (Shevchenko 2009). Sjevtsjenko, som selv står for en nasjonal-konservativ posisjon, ble i både 2008 og 2010 oppnevnt til Russlands «Samfunnskammer» (obsjstjestvennaja palata), et lov-forankret organ uavhengig av myndighetene som fører tilsyn med menneskerettighetene i Russland. Forfatteren er ikke kjent med at dette organet har utfordret noen av lovene som er omtalt i innledningen til artikkelen.

ROK er preget av den svake demokratiske kulturen som råder i Russland, der norm- og kulturbevaring fremmes gjennom lovgivning som søker å bevare det som oppfattes som tradisjonelle verdier.

\section{Innvandring og statsborgerskap}

Vi så innledningsvis at Minkenberg legger til grunn at majoritetskirkers institusjonelle interesser handler om å opprettholde sin status (Minkenberg 2009: 1195-1196), noe som rimeligvis vil påvirke deres syn på innvandring og statsborgerskap. En slik forståelse kan utfordres. Det finnes mange eksempler på kirker som har kritisert en restriktiv asylpolitikk, også hvis asylsøkerne kommer fra land dominert av en annen religion.

Den russiske grunnloven sier i artikkel 63.1: «Den russiske føderasjon skal gi politisk asyl til utlendinger og statsløse personer i henhold til anerkjente normer nedfelt i internasjonal rett». Dette uttrykker en inkluderende tilnærming, men i praksis får svært få opphold, og enda færre får asyl.

Russland er et av de landene i verden som er vert for flest statsløse, over 100000 (FNs Høykommissær for flyktninger 2015). En enda større gruppe er ukrainske flyktninger, der over 310000 er registrert av FNs Høykommissær for flyktninger. Om lag 1 million russere og ikke-russere innvandret fra de tidligere SUS-landene hvert år i de første årene etter oppløsningen av Sovjetunionen (Curtis 1996).

I tillegg til disse huser Russland millioner av migrantarbeidere, hovedsakelig fra tidligere sovjetrepublikker (ifølge Verdensbanken (2016: 22) topper Tadsjikistan og Kirgisistan listen over stater i verden der størst andel av landets verdiskapning kommer fra overføringer fra utenlandsboende, henholdsvis 36,6 og 30,3 prosent av BNP).

Russere generelt uttrykker relativt negative holdninger til personer med ikkerussisk bakgrunn (Global Post 2012) og ikke-kristne personer (Pew Global Attitudes Survey 2011: 4 og 20). Sistnevnte undersøkelse finner at henholdsvis 62 og 63 prosent har positive vurderinger av muslimer og jøder, mens 89 prosent har positive vurderinger av kristne. Religiøs intoleranse synes å dominere i områder med et lavt antall muslimer, mens personer i regioner med en mer blandet befolkning uttrykker mer tolerante holdninger (Karpov og Lisovskaya 2008). I europeisk sammenheng er russere blant de mest negative når de blir spurt om innvandrernes kulturelle bidrag. ${ }^{2}$ Knox mener ROK har bidratt til fremmedfrykt i Russland (Knox 2005).

\footnotetext{
${ }^{2}$ Ifølge European Social Survey (ESS) 2012, rapporterer 50,2 prosent av russerne at kulturlivet er «undergravd» av innvandrere (spørsmål D18 i ESS, skåre 5 eller lavere). Ifølge Blom (2010: 156) har Russland den nest laveste poengsum i vurdering av utlendingers bidrag til landets kulturliv.
} 
I Sosiallæren er flyktninger nevnt sammen med andre sårbare personer som ikke kan tjene til livets opphold (ROK 2000: VI.6), mens Menneskerettighetslæren fra 2008 ikke behandler menneskerettighetene til flyktninger, asylsøkere eller statsløse personer. Derimot løftes fram «rettigheter til nasjoner og etniske grupper» - altså folkegrupper med en lang tilstedeværelse i Russland (ROK 2008: V.2.7). Den russiske Grunnloven anerkjenner «nasjonale minoriteter» i artikkel 71.3.

Oppsummert synes det som at behandling av utlendinger ikke er høyt på agendaen til ROK, og ROK utfordrer ikke asylsystemet i Russland, som må forstås som å være utilstrekkelig (March 2012: 404). Samtidig er det verdt å merke seg at mange av dem som har kommet til Russland etter Sovjetunionens sammenbrudd har fått statsborgerskap og ikke blitt kastet ut.

Kirkens ekklesiologi og rolle $i$ "sakralisering» av nasjonen

Som nevnt over antas det at ortodokse majoritetskirker er positive til et samarbeid mellom kirke og stat i å «kristne» eller «sakralisere» hele nasjoner. Vi så ovenfor at Sosiallæren løfter fram en "ortodoks stat» (ROK 2000: III.4), men «ikke gir preferanse til noe sosialt system eller noen eksisterende politiske doktriner» (ROK 2000: III.7).

Sakralisering av nasjoner kan forstås i lys av begrepet teosis eller «guddommeliggjøring» av enkeltpersoner. I tillegg har Vladimir Solovjov (1853-1900) i sine forelesninger om guddommelig menneskelighet lansert begrepet «gudmenneske» («bogochelovek») (Breckner 2015: 124; se også Hoppe-Kondrikova et al. 2013: 208-209; for en påpekning av at begrepet snarere må knyttes til Guds menneskelighet gjennom inkarnasjonen, se Valliere 1996; se også Poole 2010). Mens altså «bogotsjelovek» vektlegges i nyere forskning på ROK, er det teosis som omtales på OrthodoxWiki (2012), og ingen omtale gis av «bogotsjelovek». Verken guddommeliggjøring eller gudmenneskelighet («bogotsjelovetsjestvo») som begge er begreper på individnivå - kan alene forklare tilbøyeligheten til å «sakralisere» nasjoner.

Ifølge ortodoks teologi må evangeliet forstås som i stand til å forandre mennesker og verden gjennom sin evne til å skape noe nytt (transfigurasjon). I tillegg forstås staten innen ortodoks teologi å inneha en gudgitt natur og derfor er kirkens medlemmer pliktige til å adlyde statlige myndigheter. Menneskerettighetene kan med disse premissene kun vurderes positivt dersom de forstås å være i samsvar med kirkens lære og evangeliet selv.

Det er minst to andre eksempler på hvordan stat og kirke i Russland fungerer gjensidig legitimerende.

For det første har begrepet «sobornost», altså den kollektive rammen for å bevare personligheten til den enkelte (Hoppe-Kondrikova et al. 2013: 207-208), blitt knyttet til teologi ved å forstås som en form for åndelig fellesskap. Tre dimensjoner ved sobornost står sentralt: frivillighet, oppgivelse av egeninteresse og underordning til fellesverdier, og kjærlighet til både kirke, nasjon og stat (Lossky 1952: 26; viser til Ivan Kirejevskij (1806-1856)). 
For det andre hevder ROK at «det ideelle samfunn kan oppstå (...) bare i den ortodokse staten» (ROK 2000: III.4). En ortodoks stat har som vi har sett ingen konstitusjonell forankring i Russland, men må forstås som en stat der ortodoks kristendom gis innflytelse. Ut fra en slik tilnærming blir det vanskelig å akseptere ROKs påstand om at kirken «ikke gir preferanse til noe sosialt system eller noen eksisterende politiske doktriner» (ROK 2000: III.7).

Denne preferansen for «den ortodokse staten» innebærer at ROK fremmer patriotisme og lojalitet til staten, men offisielt tar avstand fra etnisk nasjonalisme (ROK 2000: II.4).

Oppsummeringsvis hevder ortodoks teologi at samfunnet må forbedres gjennom et nært samarbeid mellom kirke og stat:

[S]taten er bevisst på at dennesidig velvære er utenkelig uten respekt for visse moralske normer - normer som også er avgjørende for menneskets evige frelse. Derfor kan funksjoner og visjoner for kirke og stat sammenfalle ikke bare i å fremme dennesidig velferd, men også i å oppfylle kirkens frelsende misjon (ROK 2000: III.3).

Staten hevdes altså å ha en rolle i å fremme menneskers frelse. Det kan synes som om den russiske staten er åpen for å fylle en slik rolle, både gjennom lovgivning og gjennom mer symbolske handlinger, deriblant oppføringen rett utenfor Kreml i 2016 av en statue av Vladimir I, som ble døpt til kristendommen i 988 mens han hersket over Rus-riket i Kiev.

En slik rolle for staten Russland er utfordrende, sett i lys av at Russland er multireligiøst og med en stor andel som ikke er kirkeaktive. Videre er det interessant at toleranse for ateisme i Russland synes å betinges av at ateistene ikke oppfattes som å være for aggressive mot etablert religion (Schroeder og Karpov 2013: 302-303).

\section{Avslutning}

Artikkelen løftet innledningsvis fram to tilnærminger: stiavhengighet, altså at fortiden influerer nåtiden, og en situasjonsbestemt tilnærming, der kirkers valg ikke er gitt og der allianser kan inngås og avvikles avhengig av omstendighetene. Artikkelen har vist at begge tilnærmingene er relevante. ROK har valgt å knytte seg tett til det sittende regimet, og løfte fram det som oppfattes som tradisjonelle og kollektive russiske verdier, i motsetning til innflytelsen som hevdes å komme fra den vestlige verden blant annet gjennom menneskerettighetene.

Artikkelen har vist at den russiske arven har vært pluralistisk ved å anerkjenne tradisjonelle religiøse samfunn, noe som også løftes fram av ROK (ROK 2008: V.2). På andre områder har nasjonalisme i økende grad blitt en del av den kirkelige diskursen, omtalt som en "innadvendt helliggjørelse av nasjonen ...» (Ramet 2006: 150). Videre har vi sett at ROK fremmer en partikularistisk, moralsk forståelse av menneskerettigheter, der bevaring av den nasjonal-kulturelle arv er sentralt. ROK søker altså å begrense menneskerettighetene med svært vide og subjektive begrunnelser, men den russiske stat er naturligvis ikke bundet av noen av disse dokumentene. 
De to karaktertrekkene ved majoritetskirker løftet fram innledningsvis - å fremme egne institusjonelle interesser (Minkenberg 2009: 1195), og motvilje mot å kritisere regjeringen åpenlyst (Minkenberg 2008a: 377) - må forstås å gjelde for ROK. Reflekterer dette opportunisme, autoritarianisme eller ortodoks nasjonalisme?

Opportunisme synes å være en del av forklaringen på posisjonene ROK har inntatt. Den russiske stat har en interesse i å fremme lojalitet og patriotisme, og styrke sin geopolitiske innflytelse. ROK har vært viktig i å fremme Russlands geopolitiske ambisjon, spesielt siden ROK utøver betydelig innflytelse i Ukraina og Hviterussland. Videre har ROK fått legge premissene for arbeidet med å fremme tradisjonelle verdier, både i Russland og i FNs Menneskerettighetsråd. Vi har sett at den gjennomsnittlige russer er relativt lite religiøst aktiv. ROK har søkt å opprettholde en privilegert posisjon, noe som er en logisk reaksjon når institusjoner står overfor samfunnsendringer som kan redusere institusjonens innflytelse.

I hvilken grad reflekterer ROKs posisjoner en autoritær trend i ROK? Vi ser av strukturene i ROK at kirken er patriarkalsk og udemokratisk, og selv Folkekonsilet ble initiert av patriarkatet og ledes av patriarken. De demokratiske impulser den første tiden etter kommunismens fall var ikke omfattende nok til å påvirke den overordnede strategien for ROK. Snarere virker det som at de russiske institusjonene, inkludert ROK, ikke er interessert i å gjenta erfaringene fra de demokratiske eksperimenter av 1990-tallet, og begrepet "dermokratija» ("drittstyre») har blitt brukt for å beskrive denne perioden (March 2012: 408). Videre har ROK en negativ tilnærming til «menneskeskapt lov» (ROK 2000: IV.7).

Til slutt, til tross for ROKs advarsel mot nasjonalisme og preferanse for patriotisme, er det rimelig å si at ROK både fremmer og legitimerer nasjonalisme? ROK hevder at det er «særlig farlig å fornærme religiøse eller nasjonale følelser (...)» (ROK 2008: IV.4). Denne advarselen, sammen med begrepet «ortodoks stat» (ROK 2000: III.4), gjør det vanskelig å se hvordan ROK kan hevde at de ikke fremmer og legitimerer nasjonalisme.

ROK må forstås å alliere seg med den russiske staten - i tråd med symfonitenkning - for å opprettholde den nasjonale kulturarven og bevare tradisjonelle verdier - samtidig som religiøst mangfold sikres gjennom å fremme interessene til tradisjonelle minoriteter.

ROK har en sterk alliert i det sittende russiske regimet. Det synes vanskelig å forene den religiøse tradisjonen og den stadig sterkere alliansen mellom ROK og regimet som finnes i Russland med en menneskerettighetsforståelse som finnes i vesten. Positive endringer i forståelsen av menneskerettigheter i ROK har større sannsynlighet for å lykkes dersom menneskerettigheter forstås som regelsystem, og ikke som ideologi (Horsfjord 2012: 453).

\section{Om artikkelen}

Takk til Atle Staalesen og Stephanie Dietrich for konstruktive innspill til tidligere versjoner av artikkelen. Ansvaret for mulige feil ligger utelukkende hos forfatteren. 


\section{Litteratur}

Agadjanian, Alexander (2010) "Liberal Individual and Christian Culture: Russian Orthodox Teaching on Human Rights in Social Theory Perspective». Religion, State E Society 38 (2): 97-113.

Blom, Svein (2010) Comparison of Attitudes in Norway and Other European Countries, Immigration and Immigrants. Statistical Analyses 122. Tilgjengelig på http://www.ssb.no/english/subjects/02/sa_innvand_en/sa122/ comparison.pdf. Lesedato 3. april 2017.

Breckner, Katharina A. (2013) "Comparative Study of "Godmanhood" (bogochelovechestvo) in Russian Philosophy. The Eighth Day in V. Solovëv, S. Bulgakov, N. Berdiaev, and S. Frank». The Ignatianum PhilosophicalYearbook XIX (1) 117-152. http://doi.org/10.5281/zenodo.35753.

Codevilla, Giovanni (2008) «Relations between Church and State in Russia Today». Religion, State E Society 36 (2): 113-138.

CPCE (2009) Human Rights and Morality. Tilgjengelig på http://www.leuenberg.net/sites/default/files/statement/ doc-9806-2.pdf. Lesedato 3. april 2017.

Curanovic, Alicja (2007) "The Attitude of the Moscow Patriarchate towards Other Orthodox Churches». Religion, State $\mathcal{G}$ Society 35 (4): 301-318.

Curtis, Glenn E. (1996) «Migration». I Russia: A Country Study. Washington: Library of Congress. Tilgjengelig på http://countrystudies.us/russia/30.htm. Lesedato 3. april 2017.

Davis, Nathanael (2003) A Long Walk to Church: A Contemporary History of the Russian Orthodox Church (2. utgave). Boulder: Westview Press.

Den norske Helsingforskomité (2014) Russia's Foreign Agent law: Violating human rights and attacking civil society. A Norwegian Helsinki Committee Policy Paper No. 6-2014. Oslo: Helsingforskomiteen.

FNs Høykommissær for flyktninger (2015) «Persons of Concern». Tilgjengelig på http://popstats.unhcr.org/en/ persons_of_concern. Lesedato 3. april 2017.

FNs Høykomissær for menneskerettigheter (2013) A/HRC/24/22: Summary of Information from State Members of the United Nations and Other Relevant Stakeholders on Best Practices in the Application of Traditional Values While Promoting and Protecting Human Rights and Upholding Human Dignity.

FNs Menneskerettighetsråd (2012) A/HRC/RES/21/3.

FNs Menneskerettighetsråd (2011) $A / H R C / R E S / 16 / 3$.

FNs Menneskerettighetsråd (2009) A/HRC/RES/12/21.

FNs Menneskerettighetsråds Rådgivingskomite (2012) A/HRC/22/71: Study of the Human Rights Council Advisory Committee on Promoting Human Rights and Fundamental Freedoms Through a Better Understanding of Traditional Values of Humankind.

Folkekonsilet (2006) The Orthodox Declaration on Human Rights and Dignity. Tilgjengelig på http://www. pravoslavieto.com/docs/human_rights/declaration_ru_en.htm. Lesedato 3. april 2017.

Fox, Jonathan (2008) A World Survey of Religion and the State. Cambridge: Cambridge University Press.

Furman, Dmitrii Efimovich (1994) «Religion and Politics in the Contemporary Mass Consciousness. Presentation at Roundtable on Religion and Politics in Postcommunist Russia». Russian Studies in Philosophy 33 (1): 52-65.

Gerber, Theodore P. and Sarah E. Mendelson (2001) How Russians Think about Human Rights: Recent Survey Data. Ponars Policy Memo No. 221. Tilgjengelig på http://csis.org/files/media/csis/pubs/pm_0221.pdf. Lesedato 3. april 2017.

Global Post (2012) «Russia's Xenophobia Problem». Tilgjengelig på http://www.globalpost.com/dispatch/news/ regions/europe/russia/120427/russia-xenophobia-racism-putin-immigration-reform. Lesedato 3. april 2017.

Hebly, Hans (1993) "The State, the Church and the Oikumene: the Russian Orthodox Churchand the World Council of Churches 1948-1985» i Sabrina P. Ramet (red.) Religious Policy in the Soviet Union. Cambridge: Cambridge University Press (105-122).

Hoppe-Kondrikova, Olga, Josephien van Kessel \& Evert van der Zweerde (2013) «Christian Social Doctrine East and West: The Russian Orthodox Social Concept and the Roman Catholic Compendium Compared». Religion, State E Society 41 (2): 199-224.

Horsfjord, Vebjørn L (2012) «The Russian Orthodox Church:Two Discourses on Human Rights». Nordic fournal of Human Rights 30 (4): 429-453.

Hvithamar, Annika \& Margit Warburg (2009) «Introducing Civil Religion, Nationalism and Globalisation» i Annika Hvithamar, Margit Warburg \& Brian A. Jacobsen (red.) Holy Nations and Global Identities. Leiden: Brill (1-19).

Karpov, Vyacheslav \& Elena Lisovskaya (2008) «Religious Intolerance among Orthodox Christians and Muslims in Russia». Religion, State \& Society 36 (4): 361-377. 


\section{0 | HANS MORTEN HAUGEN}

Kirill (2006) «Human Rights and Moral Responsibility. Part I/II. Paper read at the Tenth World Russian People's Council "Faith. The Person. The World. Russia's Mission in the 21st Century"». Europaica 97 \& 98. Tilgjengelig på http://orthodoxeurope.org/page/14/97.aspx. Lesedato 3. april 2017.

Knox, Zoe (2005) «Russian Orthodoxy, Russian Nationalism and Patriarch Aleksii II». Nationalities Papers 33 (4): 533-545.

Lossky, Nikolai O (1952) History of Russian Philosophy. London: Allen \& Unwin.

Madeley, John T.S. (2003) «European Liberal Democracy and State Religious Neutrality» i John T.S Madeley \& Zslot Enyedi (red.) Church and State in Contemporary Europe: the Chimera of Neutrality. London: Frank Cass (1-22).

March, Luke (2012) «Nationalism for Export? The Domestic and Foreign-Policy Implications of the New "Russian Idea"». Europe-Asia Studies 64 (3): 401-425.

Minkenberg, Michael (2008a) «Religious Legacies, Churches and the Shaping of Immigration Policies in the Age of Religious Diversity». Politics and Religion 1 (3): 349-383.

Minkenberg, Michael (2008b) «Religious Legacies and the Politics of Multiculturalism: A Comparative Analysis of Integration Policies in Western Democracies» i Ariane Chebel d'Appollonia \& Simon Reich (red.) Immigration, Integration and Security: America and Europe in Comparative Perspective. Pittsburg: University of Pittsburg Press (44-66).

Minkenberg, Michael (2009) «Religion and Euroscepticism: Cleavages, Religious Parties and Churches in EU Member States». West European Politics 32 (1): 1190-1211.

Mozgovoj, Sergej (2004) «Siloviki im Dienste der Orthodoxie: Staat, Kirche und Nation in Russland». Osteuropa 54 (1): 59-73.

Norris, Pippa and Ronald Inglehart (2011) Sacred or Secular: Religion and Politics Worldwide (2. utgave). Cambridge: Cambridge University Press.

OrthodoxWiki (2013) «Third Rome». Tilgjengelig på http://orthodoxwiki.org/Third_Rome. Lesedato 3. april 2017.

OrthodoxWiki (2012) «Theosis». Tilgjengelig på https://orthodoxwiki.org/Theosis. Lesedato 3. april 2017.

OrthodoxWiki (2010) «Political Ethics». Tilgjengelig på http://orthodoxwiki.org/Political_ethics. Lesedato 3. april 2017.

Pankhurst, Jerry \& Alar Kilp (2013) «Religion, the Russian Nation and the State: Domestic and International Dimensions: an Introduction». Religion, State E Society 41 (3): 226-243.

OSSE (2017) Defamation and Insult Laws in the OSCE Region: A Comparative Study. Tilgjengelig på http://www. osce.org/fom/303181?download=true. Lesedato 7. august 2017.

Papadakis, Aristeides (1983) «The Historical Tradition of Church-State Relations under Orthodoxy» i Pedro Ramet (red.) Eastern Christianity and Politics in the Twentieth Century. Durham: Duke University Press (37-58).

Pew Global Attitudes Survey (2011) Muslim-Western Tensions Persist. Tilgjengelig på http://www.pewglobal.org/ files/2011/07/Pew-Global-Attitudes-Muslim-Western-Relations-FINAL-FOR-PRINT-July-21-2011.pdf. Lesedato 3. april 2017.

Poole, Randall A. (2010) «Vladimir Solov'ëv's Philosophical Anthropology: Autonomy, Dignity, Perfectibility" i G. M. Hamburg \& Randall A. Poole (red.) A History of Russian Philosophy 1830-1930: Faith, Reason, and the Defense of Human Dignity. Cambridge \& New York: Cambridge University Press (131-149).

Radio Free Europe (2006) «Russian Church Blames Hate Crimes On Amorality». Tilgjengelig på http://www. rferl.org/content/article/1067394.html. Lesedato 3. april 2017.

Ramet, Sabrina (2006) "The way we were - and should be again? European Orthodox Churches and the "idyllic past" i Timothy A. Byrnes and Peter J. Katzenstein (red.) Religion in an Expanding Europe. Cambridge: Cambridge University Press (148-75).

Ramet, Sabrina (1998) Nihil Obstat: Religion, Politics and Social Change in East-Central Europe and Russia. Durham: Duke University Press.

Ramet, Pedro (1989) «The Interplay of Religious Policy and Nationalities Policy in the Soviet Union and Eastern Europe» i Pedro Ramet (red.) Religion and Nationalism in Soviet and East European Politics, revidert utgave. Durham: Duke University Press (3-41).

Ramet, Pedro (1983) "Autocephaly and National Identity in Church-State Relations in Eastern Christianity: An Introduction" i Pedro Ramet (red.) Eastern Christianity and Politics in the Twentieth Century. Durham: Duke University Press (3-19).

ROK (2015) Regular session of the Supreme Church Council of the Russian Orthodox Church chaired by His Holiness Patriarch Kirill takes place. Tilgjengelig på https://mospat.ru/en/2015/11/23/news125486. Lesedato 3. april 2017. 
ROK (2013) Statute of the Russian Orthodox Church adopted by the Bishops' Council in 2000, amended by the Bishops'Council in 2008 and 2011 and adopted as amended by the Bishops'Council in 2013. Tilgjengelig på https:// mospat.ru/en/documents/ustav. Lesedato 3. april 2017.

ROK (2011) The Russian Orthodox Church's Approach to Willful Public Blasphemy and Slander against the Church. Tilgjengelig på https://mospat.ru/en/documents/otnoshenie-russkojj-pravoslavnojj-cerkvi-knamerennomu-publichnomu-bogokhulstvu-i-klevete-v-adres-cerkvi. Lesedato 3. april 2017.

ROK (2008) The Russian Orthodox Church's Basic Teaching on Human Dignity, Freedom and Rights. Tilgjengelig på https://mospat.ru/en/documents/dignity-freedom-rights. Lesedato 3. april 2017.

ROK (2000) Bases of the Social Teaching of the Russian Orthodox Church. http://orthodoxeurope.org/page/3/14. aspx. Lesedato 3. april 2017.

Russkiy Mir Foundation (2014) Russian World Values Unite Different Peoples of Historical Rus - Patriarch Kirill. Tilgjengelig på http://russkiymir.ru/en/fund/press/154311. Lesedato 3. april 2017.

Shevchenko, Maxim (2009) Is Religious Freedom Deteriorating in Russia? Tilgjengelig på http://rt.com/ Politics/2009-05-06/Is_religious_freedom_deteriorating_in_Russia.html/print. Lesedato 3. april 2017.

Schroeder, Rachel and Vyacheslav Karpov (2013) «Russia's Desecularizing Regime». Religion, State E Society 41 (3): $284-311$.

Smith, Anthony D. (2009) "Hierarchy and Covenant in the Formation of Nations» i Annika Hvithamar, Margit Warburg \& Brian A. Jacobsen (red.) Holy Nations and Global Identities. Leiden: Brill (21-45).

Soldatov, Aleksandr (2004) «Religion und Staat. Die Russisch Orthodoxe Kirche und der geistliche Raum Russlands». Osteuropa 54 (1): 74-81.

SRAS (2013) «Russia's Gay “Propaganda” Law». Tilgjengelig på http://www.sras.org/russia_gay_propaganda_ law. Lesedato 7. august 2017.

Staalesen, Atle (2004) "Orthodoxy and Islam in Post-Soviet Russia: Opposing Confessional Cultures or Unifying Force? " i Pål Kolstø \& Helge Blakkisrud (red.) Nation-Building and Common Values in Russia. Lanham: Rowman \& Littlefield (301-25).

Stoeckl, Kristina (2016) The Russian Othodox Church as a Moral Norm Entrepreneur». Religion, State E Society 44 (2): 132-151.

Stoeckl, Kristina (2014) The Russian Orthodox Church and Human Rights. Abingdon \& New York: Routledge.

Stoeckl, Kristina (2012) "The Human Rights Debate in the External Relations of the Russian Orthodox Church". Religion, State \& Society 40 (2): 212-232.

Tjønn, Halvor (2015) Russland blir til. Fra vikingene til Ivan den grusomme. Oslo: Dreyer.

Valliere, Paul (1996) «Sophiology as Orthodox with Modern Civilization» i Judith Deutsch Kornblatt \& Richard F. Gustafson (red.) Russian Religious Thought. Madison:University of Wisconsin Press (176-192).

Verdensbanken (2016) Migration and Development Brief 26. Washington D.C.: Verdensbanken.

Vetvik, Einar (1992) «Religion and State from a Western Christian Perspective» i Jørgen Nielsen (red.) Religion and Citizenship in Europe and the Arab World. London: Grey Seal (7-24).

Walters, Philip (1993) "A survey of Soviet Religious Policy» i Sabrina P. Ramet (red.) Religious Policy in the Soviet Union. Cambridge: Cambridge University Press (3-30).

Østbø, Jardar (2016) The New Third Rome. Readings of a Russian Nationalist Myth. New York: ibidem Press. 